\title{
Survival Analysis of Covid 19 Patients from Two Hospitals in Cimahi, Indonesia
}

\author{
Desy Linasari* \\ Department of Public Health, Faculty of Medicine \\ Universitas Jenderal Achmad Yani \\ Cimahi, Indonesia \\ *desy.linasari@lecture.unjani.ac.id
}

\begin{abstract}
The Coronavirus Disease (COVID-19) outbreak is still evolving globally and remains a Public Health Emergency of International Concern (PHEIC). This study was conducted to find out the survival probability of patients suffering from covid after the patients were hospitalized for one month in Dustira hospital and RSUD Cibabat. The study design used retrospective cohort study, with data analysis using survival analysis employing life table and Kaplan Meier. From the clinical symptoms it was found that the most complaints were among others fever, cough, throat pain, throws up, and anosmia with $88,1 \%, 85,1 \%, 50,6 \%, 56,5 \%$ and $26,2 \%$ respectively. Survival probability of males and females was $49 \%$ and $33 \%$ respectively. The covid patients with comorbid factors had a lower survival probability than those without comorbid ones. The covid patients hospitalized in Dustira Hospital and RSUD Cibabat were those showing the symptoms from the beginning of the disease, and the dead patients were those with comorbid factors. Hypertension is a factor that increases the risk of death in Covid 19 patients. Hypertensive patients are advised to keep control and take medication regularly to reduce the risk of death if infected Covid 19.
\end{abstract}

Keywords-survival analysis, Covid 19, life table -Kaplan Meier

\section{INTRODUCTION}

Corona virus has been found since 1930 and it was only found in animals. In 2002. A new corona virus infecting humans and causing Severe Acute Respiratory Syndrome (SARS) disease was found [1]. In December 2019, in Wuhan, Hubei Province, Tiongkok a case of mysterious pneumonia with unknown cause was reported, and in 3 days the number of cases reached 44 people and still counted until reaching million cases [2]. On 11th of February 2020 WHO announced the virus under the name Severe Acute Respiratory Syndrome Coronavirus-2 (SARS-Cov 2) and the name of the disease was Coronavirus Disease 2019 (COVID 19) [1].

Indonesia reported the first Covid case on 2nd of March 2020. Up to present time, millions of Indonesian citizens have been infected by the Covid with thousands of whom died [3]. On 11th of march 2020 , WHO announced the declaration that COVID 19 became pandemic in the world. On 6th of January 2021, the total number of covid cases in the world reached 105 millions with 2,3 millions of the patients died [4]. The transmission of Covid disease was very fast, and there has been no cure for the disease yet.

The incubation period for COVID-19 is thought to extend to 14 days, with a median time of 4-5 days from exposure to symptoms onset. One study reported that $97.5 \%$ of people with COVID-19 who have symptoms will do so within 11.5 days of SARS-CoV-2 infection [5,4].

The symptoms and clinical signs of covid 19 found in 95 patients suffering from covid 19 are among others fever, coughing, dyspnea, myalgia, sore throat, expectoration, anosmia, anorexia, nausea, and diarrhea. There were some patients reported to suffer from headache up to convulsion [69] In severe cases there can be organ dysfunction such as shock, acute respiratory distress syndrome [ARDS], acute cardiac injury, and acute kidney even death. 8 There is no specific treatment available for SARS-CoV-2, and the current treatment relies on supportive care of the infected patients.

Based on a study in China, when entering the hospital, there were many patients with at least one comorbid factor, comorbid factor of diabetes mellitus with at least $10-20 \%$, hypertension with $10-15 \%$, and cardiovascular diseases reaching nearly $40 \%$. The comorbid factor is linked to the increasing risk of respiratory disorder syndrome as high as 3,4 times higher. The covid patients with comorbid factor will suffer from respiratory failure more, which ends up with death [10].

A study conducted by Wang et al. [11], in 2 hospitals in Wuhan found that as many as $68,4 \%$ of the covid patients with more than one comorbid factors died. The prevalence of covid 19 patient dying with comorbid factors are among others accompanied by hypertension $52,6 \%$, cardiovascular disease $36,8 \%$, DM as many as $26,3 \%$, and chronic kidney disease as many as $5,3 \%$.

According to the Center for disease control and prevention (CDC) covid 19 virus spreads through close contact between human and human including those who are physically close within the distance of 1,5 to 2 meters. Such a person has a high risk of getting infected with this disease. An infected person 
with this virus without the signs can also spread the virus to others. When Covid 19 sufferers cough, sneeze, sing, talk and breathe, they will spill droplets. When inhaled by others, this droplet will cause the inhaler to get infected. There are some proofs that this covid virus infects the people with the distance of more than 2 meters, that is the transmission in a closed room with insufficient ventilation [12].

A fast and accurate detection of Covid is very important in controlling the covid 19 outbreak. Currently the most accurate diagnostic test used is reverse-transcription polymerase chain reaction (RT-PCR). It is better to use nasofaring samples compared to throat samples for the sample used in this examination. SARS Cov2 virus can also be found in faeces and blood [13].

Dustira hospital is one of the referred hospitals for COVID 19 patients. Since the beginning of the pandemic of covid 19, which was in march, Dustira hospital has been giving its service to covid 19 patients. With the many patients of Covid 19 being treated in Dustira Hospital and Cibabat Hospital, the researcher intended to find out the survival probability of covid patients in Dustira Hospital.

\section{METHODS}

\section{A. Study Design and Data Collection}

The design in the study used cohort retrospective. Cohort study design is the type of non-experimental epidemiology study often used to study the relationship between the risk factors and effect or disease [14]. The cohort design used in this research used retrospective cohort study, which means that the exposure took place before the researcher started his or her study.

The data used was the secondary data from Dustira hospital starting from 2nd of March 2020 to 31st of December 2021. The number of samples in this study was 168 in-patient covid patients in Dustira Hospital and Cibabat Hospital. The patient was confirmed covid positive with PCR supporting examination. Observation was done from the first day of treatment up to the release of the patient from the hospital in a healthy state or suffering from event/death.

\section{B. Statistical Method}

Univariable data analysis was done to demonstrate the distribution of patients' characteristic and study variables. Descriptive data analysis used a frequency menu and cross tab to know the distribution of characteristic data with the status of patient's survival. Bivariable data analysis was done by using survival analysis employing table life method and Kaplan Meier method. Survival analysis is a collection of statistical procedures to analyse the data where the outcome variable under the study is the time span required from the beginning until the event emerges. Time variable in this research is the span of time a covid 19 patient is hospitalized in the hospital. The event in this study was the death of Covid-19 patient treated.
The table life method was to identify the number of terminal events, median survival time and cumulative probability of surviving covid 19 patients. Kaplan Meier method was used to compare the survival between the dead covid patients and the survived ones. From the Kaplan Meier analysis, the Kaplan Meier curve showing survival rate was drawn. $Y$ axis in the survival curve shows the percentage of subjects surviving or alive and $\mathrm{x}$ axis shows time. The winding line is the survival line [15].

Kapplan Meier curve is also used to check the hazard proportional assumption. The survival curve which does not intersect is the one that fulfills the proportional hazard and the one that intersects does not meet the proportional hazard. The curve fulfilling the proportional hazard is continued with coxregression analysis. The curve which does not meet the proportional hazard is continued with time-dependent Cox Regression analysis [16,17].

The result of Cox Regression analysis is hazard ratio. The incidence rate is the speed of an event which is mathematically the comparison between the incidence and time (person time). Another name of incidence rate is hazard. Therefore, hazard ratio is the comparison of incidence rate [15]

\section{RESULTS}

\section{A. Univariable Analysis}

The number of samples collected from 2nd of March 2020 to 31 st of December 2020 was 168 Covid 19 patients consisting of 160 surviving patients and 8 dead patients. The figures on characteristics and clinical signs can be seen in Table 1. More women were infected with Covid 19 than men with $53 \%$ and $53 \%$ respectively. Most of covid patients showed fever, with only $11.9 \%$ not suffering from fever. The second most complained symptom was coughing with $85,1 \%$. The third most complained symptom was dyspnea with $74.4 \%$ and those who suffered from severe pneumonia reached $16.7 \%$.

The patients complained about the clinical signs from not only the respiratory but also digestion problems starting from anorexia, nausea and diarrhea. The most complaints from the covid patients of the digestion tract were nausea with $56,5 \%$.

TABLE I. The Figure ON CHARACTERISTICS AND CLINICAL SignS BASED ON COVID 19 PATIENTS' SuRVIVAL STATUS IN DustiRa HOSPITAL AND CIBABAT HOSPITAL.

\begin{tabular}{|l|l|}
\hline Variable \\
\hline N=168 \\
\hline Age & \\
\hline$<60$ years \\
$\geq 60$ years & $133(79,2 \%)$ \\
\hline Fever & $35(20,8 \%)$ \\
\hline Yes & $148(88,1 \%)$ \\
No & $20(11,9 \%)$ \\
\hline Cough & $143(85,1 \%)$ \\
\hline Yes & $25(14,9 \%)$ \\
No &
\end{tabular}


Table 1. Cont

\begin{tabular}{|c|c|}
\hline \multicolumn{2}{|c|}{ Anosmia } \\
\hline Yes & $44(26,2 \%)$ \\
\hline No & $124(73,8 \%)$ \\
\hline \multicolumn{2}{|c|}{ Dyspnea } \\
\hline Yes & $125(74,4 \%)$ \\
\hline No & $43(25,6 \%)$ \\
\hline \multicolumn{2}{|c|}{ Severe Pneumonia } \\
\hline Yes & $28(16,7 \%)$ \\
\hline No & $140(83,3 \%)$ \\
\hline \multicolumn{2}{|c|}{ Diarrhea } \\
\hline Yes & $43(25,6 \%)$ \\
\hline No & $125(74,4 \%)$ \\
\hline \multicolumn{2}{|c|}{ Nausea } \\
\hline Yes & $95(56,5 \%)$ \\
\hline No & $73(43,5 \% 0$ \\
\hline \multicolumn{2}{|c|}{ Anorexia } \\
\hline Yes & $31(18,5 \%)$ \\
\hline No & $137(81,5 \%)$ \\
\hline
\end{tabular}

In Table 2 the covid patients who died and had hypertension as the comorbid were $11,1 \%$ while those with DM as comorbidity were $10 \%$. As many as $4,3 \%$ of the covid patients who passed away had heart disease and as many as $3,6 \%$ had kidney failure. The number of obese patients who passed away was $3,6 \%$.

TABLE II. THE FIGURES ON COMORBID FACTORS BASED ON SURVIVAL STATUS AT COVID 19 PATIENTS.

\begin{tabular}{|l|l|l|}
\hline \multicolumn{1}{|c|}{ Variable } & \multicolumn{1}{c|}{ Dead Patients } & Survived \\
\hline Hypertension & $6(11,1 \%)$ & $48(88,9 \%)$ \\
\hline Yes & $2(1,8 \%)$ & $112(98,2 \%)$ \\
No & $3(10,0 \%)$ & $27(90,0 \%)$ \\
\hline DM & $5(3,6 \%)$ & $133(96,4 \%)$ \\
\hline Yes & \multicolumn{2}{|l|}{} \\
No & $1(3,6 \%)$ & $27(96,4 \%)$ \\
\hline Kidney Failure & $7(5,0 \%)$ & $133(95 \%)$ \\
\hline Yes & $1(4,3 \%)$ & $22(95,7 \%)$ \\
No & $138(95,2 \%)$ \\
\hline Heart Disease & $7(4,8 \%)$ & \\
\hline Yes &
\end{tabular}

\section{B. Survival Analysis}

Based on the table life analysis it was obtained that female survival probability in 30 days was as high as $76 \%$, while for male it was $71 \%$. Survival time Median of female was 20 days, while Survival time Median for male was 28 days. The number of women who died in the first interval, from the moment the patient entered the hospital up to the 4th day, was 2 persons and for male there was no death.

In the Kaplan Meier curve (Fig. 1) it can be seen in table 1 that the female survival graph is above the male one, which can be translated as that the probability of female survival is better than that of the male one. The result from log-rank tests difference was $\mathrm{p}$ value 0,423 which shows that there was no significant difference between the male and female survival.

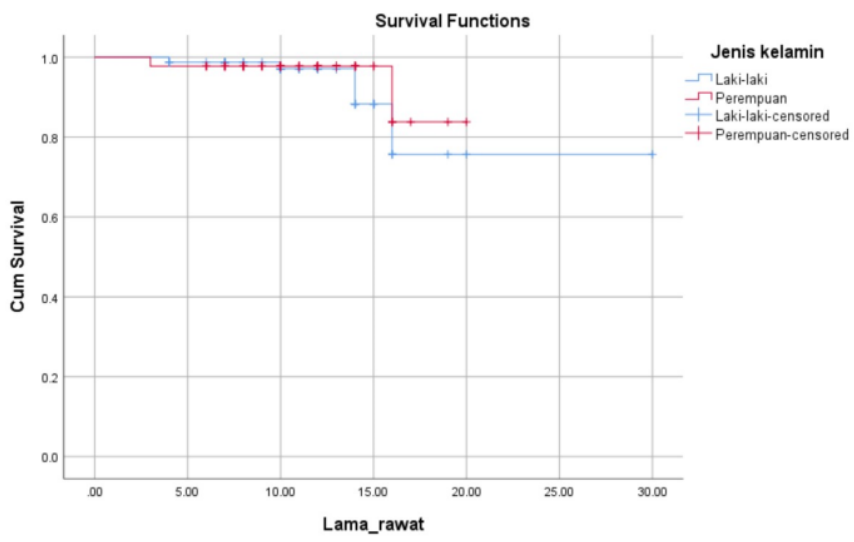

Fig. 1. Kaplan Meier Curve on Covid 19 patient survival function based on sex.

Survival time median of covid patients at the age $<60$ years was 28 days and at the age $\geq 60$ years was 17,6 days. The probability of survival of Covid patients whose age was $<60$ years was $85 \%$, and those of $\geq 60$ years was o\%.

From Fig. 2 it can be seen that the probability of patients whose age was $<60$ years was higher than that of $\geq 60$ years. Log-rank test obtained $\mathrm{P}=0,005$, which shows that there was a significant difference of survival rate between the covid patients whose ages were $<60$ years than those of $\geq 60$ years. From the Cox regression test it was obtained that HR was 6,2 with $\mathrm{P}$ value of 0,013 . HR 6,2 can be translated as that the Covid patients whose ages were $\geq 60$ years had a risk to die faster 6,2 times compared to those of age $<60$ years.

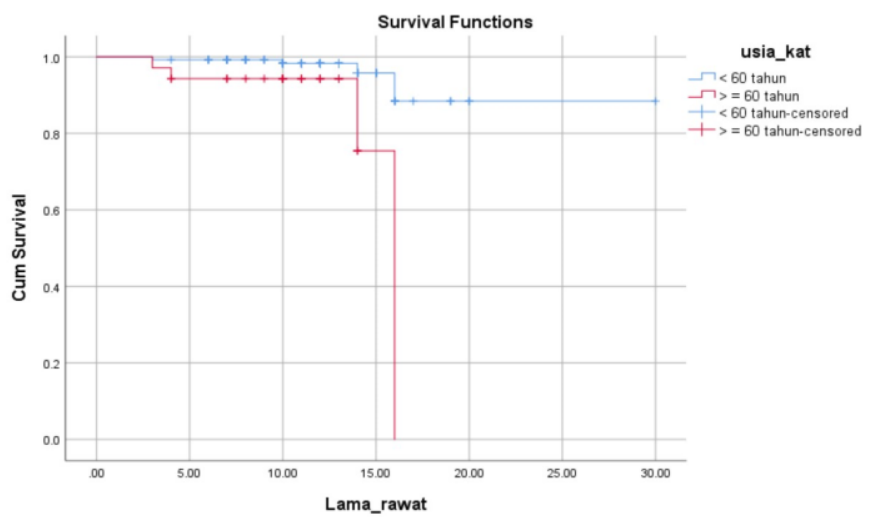

Fig. 2. Kaplan Meier Curve on survival function of Covid 19 patients based on age.

The survival probability of Covid patients with Diabetes Melitus was $47 \%$ and that of without DM was $81 \%$. From Fig. 3 it can be seen that the probability of the patients without DM history was higher compared to those of DM history. Log-rank test obtained $\mathrm{P}=0,189$, which shows that there was no significant difference of survival between covid patients with DM history and those without DM history. 


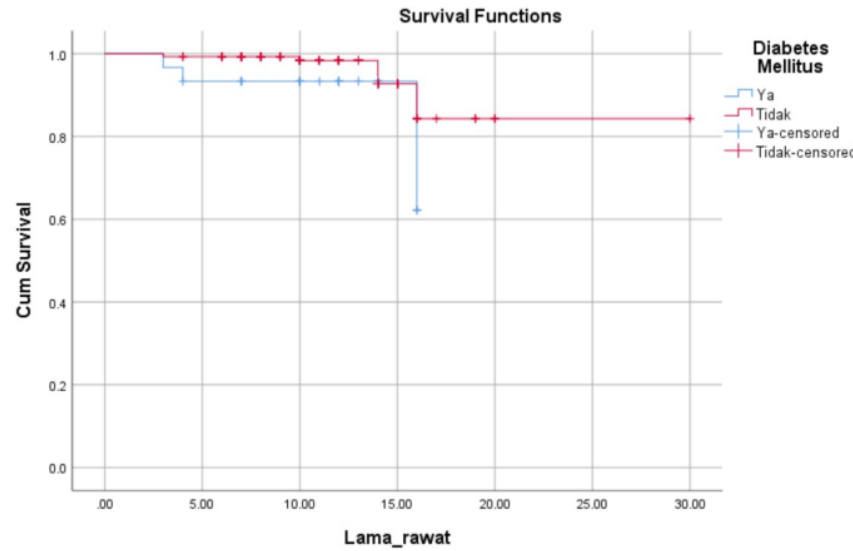

Fig. 3. Kaplan Meier Curve on survival of Covid 19 patients based on Diabetes Mellitus.

The survival probability of Covid patients with hypertension history was $47 \%$ and that of without hypertension History was $98 \%$. From Fig. 4 it can be seen that the probability of patients without hypertension history was higher than that of the patients with hypertension history. Log-rank test obtained $\mathrm{P}=0,012$ which shows that there was a significant difference of survival between patients with hypertension History and those without hypertension History. As the curve at Kaplan Meier does not meet the proportional hazard due to the curves which intersect, the analysis was continued with time-dependent Cox Regression. From the result of timedependent Cox Regression it was obtained that $\mathrm{HR}=6,039$ with $P$ value of 0,028 . HR of 6,039 can be translated as that the Covid patients with hypertension history had a risk of death 6,039 times faster compared to those without the hypertension History.

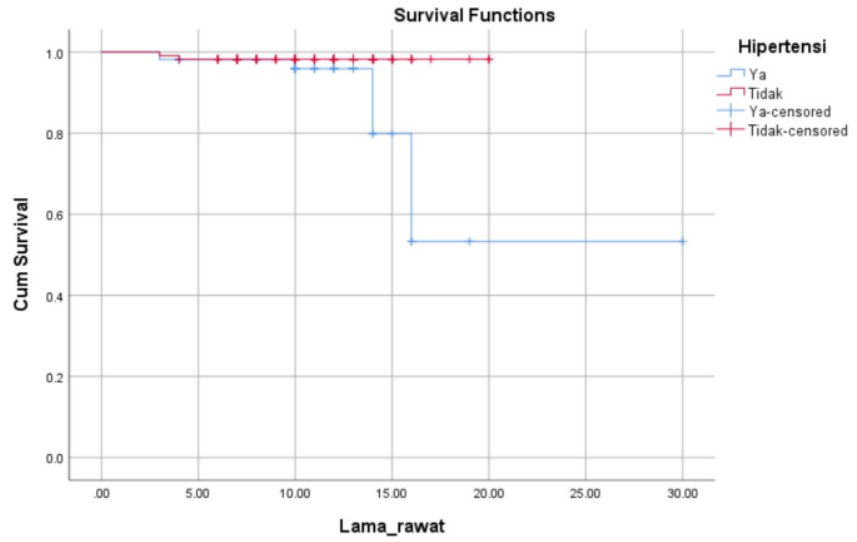

Fig. 4. Kaplan Meier Curve of survival function of Covid 19 patients based on hypertension.

The number of Covid patients with severe pneumonia was 28 patients consisting of 5 with severe pneumonia deaths and 23 with severe pneumonia still alive. From the analysis result of the life table, the survival of covid 19 patients with severe pneumonia was $40 \%$ and those without severe pneumonia was $84 \%$. From Fig. 5 it can be seen that the probability of patients without severe pneumonia was higher compared to that of those with severe pneumonia. Log-rank test obtained $\mathrm{P}=$ 0,000 , which shows that there was a significant difference of survival between the covid patients suffering from severe pneumonia and those without severe pneumonia.

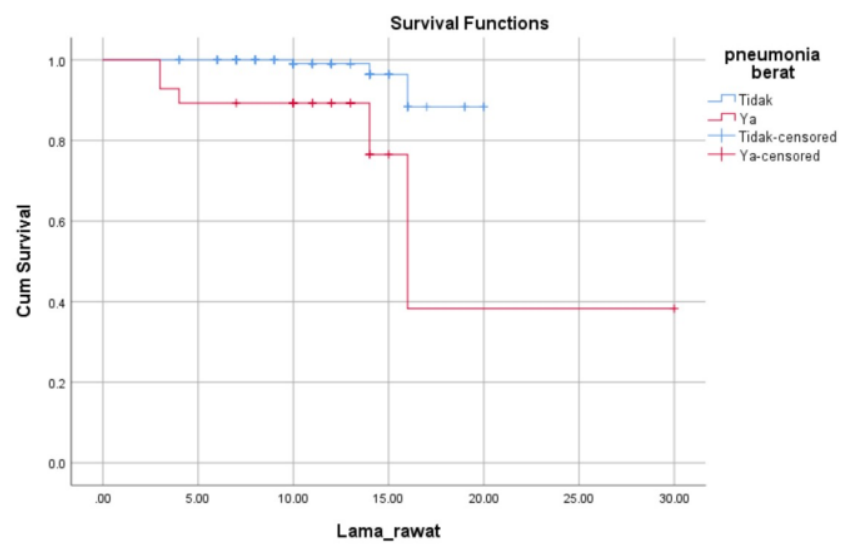

Fig. 5. Kaplan Meier Curve on survival function of Covid 19 patients based on severe pneumonia.

From Cox regression test it was obtained that HR 8,81 with $\mathrm{P}$ value of 0,003 . HR 8,81 can be translated as that Covid patients suffering from severe pneumonia had mortality risk 8,81 times faster than those without severe pneumonia.

\section{DISCUSSION}

The percentage of covid 19 patients who died in this study was $4,8 \%$, the percentage of the Covid patients mortality is not significantly different from that done by Wang in Wuhan China [8]. From study data collected in two hospitals in Wuhan China, it was found that the cause of covid patients death can be due to acute respiratory distress syndrome, septic shock, hemorrhagic shock (ARDS), acute myocardial infarction. Multiple organ failure can also happen to the covid patients which can lead to death [11] Overactive immune response together with the efect of lytic virus in the host caused pathogenesis so the patients would immediately enter the state of ARDS, then becoming septic shock and finally multiple organ failure and approximately $10 \%$ of the patients died [18].

The laboratory examination results related to covid patients' death were among others white blood cell counts > $10 \times 109 / \mathrm{L}$, neutrophils $>6.3 \times 109 / \mathrm{L}, \mathrm{CD} 3+\mathrm{CD} 8+\mathrm{T}$ cells $\leq 75$ cell $/ \mu \mathrm{L}$, cardiac troponin $\mathrm{I} \geq 0.05 \mathrm{ng} / \mathrm{mL}$, myoglobin $>100$ $\mathrm{ng} / \mathrm{L}$, creatinine $\geq 133 \mu \mathrm{mol} / \mathrm{L}, \mathrm{D}$-dimer $\geq 0.5 \mathrm{mg} / \mathrm{L}$, and $<60$ $\mathrm{mmHg}[19]$.

Meta Analysis results reported that there were more male covid patients than female covid patients. For Virus Mers-CoV and SARS-CoV there were also more male patients found than female. This is probably due to the nature of female that has a strong and adaptive immune system [20]. Male and female respond differently toward RNA and DNA virus infection, this is due to the steroid hormone, which depends on sex. The testosterone hormone has an effect of suppressing the innate 
immune response while estrogen hormone has the function of suppressing immune when the concentration is high and stimulating when the concentration is low [21].

Some research found that the number of female Covid 19 patients was more than that of the male one [19,22-24]. The result of this study was that the probability of male for the death was lower compared to that of female. This was also revealed in a study in Beijing China that the percentage of male was higher in the group which died. Male gender is one of the bad risk factors and tends to show serious signs so it can cause deaths [22].

In this research it was obtained that ages older than 60 years are the risk factor for the death to happen in the covid cases. Some studies also concluded the same that the old age factor is a risk factor of covid 19 patient mortality. The elderly group is more susceptible to SARS-CoV 2 virus disease, and this is probably related to their higher comorbid factors compared to the younger ages'. The Covid 19 signs happening at old age tend to be more severe. One of the studies reported that starting from the first day or the treatment in hospital the Covid patients of old age with pneumonia showed bad results. They were confirmed to have high $\mathrm{D}$ dimer, and this increasing $\mathrm{D}$ dimer is an independent predictor of death [19,20,25,26]. Protecting the elderly from covid 19 infection is very important, as old age is one of the risk factors which increase the prevalence of death.

In this research, the probability of survival of covid patients with DM history was lower than that of without DM history. According to some research, DM is one of the comorbid factors that can increase the risk of having the more severe symptoms, complications and even death [10,20,27-29].

In the United States, Case Fatality Rate of covid patient with DM was $8,4 \%$, the second highest after cardiovascular disease (CVD) with 13,2\% [29]. However, the presence of type 2 diabetes (T2DM) in individuals younger than 40 years (earlyonset T2DM) substantially increases the risk of hospitalization and death due to COVID-19 [28]. For instance, diabetes occurs in part because the accumulation of activated innate immune cells in metabolic tissues leads to the release of inflammatory mediators, especially IL- $1 \beta$ accumulation of activated innate immune cells in metabolic tissues leads to the release of inflammatory mediators, especially IL- $1 \beta$ and TNF $\alpha$, which promote systemic insulin resistance and $\beta$-cell leads to the release of inflammatory mediators, especially IL- $1 \beta$ and TNF $\alpha$, which promote systemic insulin resistance and $\beta$-cell damage. Additionally, metabolic and TNF $\alpha$, which promote systemic insulin resistance and $\beta$-cell damage. Additionally, metabolic disorders may lead to low immune function by impairing macrophage and lymphocyte function which may make individuals more susceptible to disease [20].

The mechanisms in patients with DM which increases the susceptibility to Covid among others are the higher cell affinity binding, which makes the viruses easy to enter, the decreasing virus clearance, the decreasing $\mathrm{T}$-sel function, the increasing susceptibility to hyper-inflammation and Cytokine-storm syndrome.

Covid 19 virus activates the host by using ACE2 enzyme. The spike or special glycoproteins in the virus make it easy for the viruses to unite with ACE2 and enter the host cell [30]. ACE2 is found to be abundant in the tissue, the highest concentration is in the soft intestine, liver, ureter, and adrenal gland. The lowest concentration is in the blood, lymph, bone marrow, brain, blood vessel and muscle. ACE2 in the normal state circulates in a small amount and is mostly not detected in a healthy state, but in the events of heart failure, hypertension, valvular heart disease, obesity, DM and other pathology conditions the amount may increase [27]. A Covid patient with hypertension has a far higher risk of death compared to that with normotension. The risk of death in covid patients with hypertension is 3,36 times higher. Based on the analysis derived from a backward stepwise logistic regression analysis it was obtained: male; age $\geq 60$ years; smoking history; hypertension; lymphocyte $\leq 0.8 * 109 / \mathrm{L} ; \quad \mathrm{PO} 2 / \mathrm{FiO} 2 \leq 260$; logistic regression analysis: male; age $\geq 60$ years; smoking history; hypertension; lymphocyte $\leq 0.8 * 109 / \mathrm{L} ; \mathrm{PO} 2 / \mathrm{FiO} 2 \leq$ 260 ; IL- $6 \geq 13 \mathrm{pg} / \mathrm{ml}$; IL-2R $\geq 1000 \mathrm{pg} / \mathrm{ml}$; positive sputum or sanguine culture for bacteria; fungi infection; multilobular infiltration [31,32]. Pneumonia is reported to be the most frequent cause of death in Covid 19 disease both for adults and children [33]. Severe COVID-19 disproportionately affects older individuals and patients with comorbidities that include diabetes, obesity, hypertension, cardiovascular disease, chronic kidney disease, and chronic lung disease [28].

\section{CONCLUSION}

The proper and fast handling to Covid patients with comorbid factors are imperative and for the people with the comorbid factors of Hypertension and DM, they should always consult with doctors and have a regular check. Community health policy and community obedience in running the health protocol is required. The elderly in the community with hypertension are suggested to improve their health and follow the health protocol during Covid 19 pandemic.

\section{ACKNOWLEDGMENT}

This work was supported by a grant from LPPM Jenderal Achmad Yani University.

\section{REFERENCES}

[1] Sutaryo, N. Yang, L. Sagoro, and D.S Sabrina, Buku Praktis Penyakit Virus Corona 19 (Covid-19), Yogyakarta: Gadjah Mada University Press, 2020. pp1-21.

[2] E. Burhan, A.D. Susanto, F. Isbaniah, S.A. Nasution, E. Ginanjar, and C.W. Pitoyo, Pedoman Tatalaksana Covid 19 . Edisi 3, Jakarta: Perhimpunan Dokter Anestesiologi dan Terapi, 2020

[3] Ihsanudin, Ini Pengumuman Lengkap Jokowi soal 2 WNI Positif Corona, Kompas, 2020. [Online] Retrieved from: https://nasional.kompas.com/read/2020/03/02/12002701/inipengumuman-lengkap-jokowi-soal-2-wni positif-corona?page=all 
[4] Worldometer, COVID-19 CORONAVIRUS PANDEMIC, 2020. [Online] Retrieved from: https://www.worldometers.info/coronavirus/

[5] Interim Clinical Guidance for Management of Patients with Confirmed Coronavirus Disease (COVID-19), 2019. [Online] Retrieved from: https://www.cdc.gov/coronavirus/2019-ncov/hcp/clinical-guidancemanagement-patients.html

[6] J. Tomlins, F. Hamilton, S. Gunning, C. Sheehy, E. Moran, and A. MacGowan, "Clinical Features of 95 Sequential Hospitalised Patients with Novel Coronavirus 2019 Disease (COVID-19), the First UK Cohort," J. Infect., vol. 81, no. 2, pp. e59-e61, 2020.

[7] C. Huang, Y. Wang, X. Li, L. Ren, J. Zhao, Y. Hu, L. Zhang, G. Fan, J. $\mathrm{Xu}$, and X. Gu, "Clinical Features of Patients Infected with 2019 Novel Coronavirus in Wuhan, China," Lancet, vol. 395, no. 10223, pp. 497506, 2020.

[8] D. Wang, B. Hu, C. Hu, F. Zhu, X. Liu, J. Zhang, B. Wang, H. Xiang, Z Cheng, and Y. Xiong, "Clinical Characteristics of 138 Hospitalized Patients with 2019 Novel Coronavirus-Infected Pneumonia in Wuhan, China," Jama, vol. 323, no. 11, pp. 1061-1069, 2020

[9] W. Guan, Z. Ni, Y. Hu, W. Liang, C. Ou, J. He, L. Liu, H. Shan, C. Lei, and D.S.C. Hui, "Clinical Characteristics of Coronavirus Disease 2019 in China," N. Engl. J. Med., vol. 382, no. 18, pp. 1708-1720, 2020.

[10] W. Guan, W. Liang, Y. Zhao, H. Liang, Z. Chen, Y. Li, X. Liu, R. Chen, C. Tang, and T. Wang, "Comorbidity and Its Impact on 1590 Patients with COVID-19 in China: A Nationwide Analysis," Eur. Respir. J., vol. 55 , no. 5, 2020.

[11] D. Wang, Y. Yin, C. Hu, X. Liu, X. Zhang, S. Zhou, M. Jian, H. Xu, J. Prowle, and B. Hu, "Clinical Course and Outcome of 107 Patients Infected with the Novel Coronavirus, SARS-CoV-2, Discharged from Two Hospitals in Wuhan, China," Crit. Care, vol. 24, no. 1, pp. 1-9, 2020.

[12] CDC. How COVID-19 Spreads, 2019. [Online] Retrieved from: https://www.cdc.gov/coronavirus/2019-ncov/prevent-getting-sick/howcovid-spreads.html

[13] P. Zhai, Y. Ding, X. Wu, J. Long, Y. Zhong, and Y. Li, "The Epidemiology, Diagnosis and Treatment of COVID-19," Int. J. Antimicrob. Agents, vol. 55, no. 5, p. 105955, 2020.

[14] A. Susilo, C.M. Rumende, C.W. Pitoyo, W.D. Santoso, M. Yulianti, H. Herikurniawan, R. Sinto, G. Singh, L. Nainggolan, and E.J. Nelwan, "Coronavirus Disease 2019: Tinjauan Literatur Terkini," J. Penyakit Dalam Indones., vol. 7, no. 1, pp. 45-67, 2020.

[15] M. Sopiyudin, Analisis Survival: dasar-dasar teori dan aplikasi dengan program SPSS. 1st ed. Jakarta: PT.Epidemiologi Indonesia; 2012. pp 526.

[16] K.H.S. Yasril, Analisis Multivariat Untuk Penelitian Kesehatan. Yogyakarta: Mitra Cendiki, 2009.

[17] S. Sastroasmoro and S. Ismael, Dasar-dasar penelitian metodologi penelitian klinis. Jakarta: Sagung Seto, 2011.

[18] F.R.S. Prakoeswa, "Dasamuka Covid-19," Medica Hosp. J. Clin. Med., vol. 7, no. 1A, pp. 231-240, 2020.

[19] R.-H. Du, L.-R. Liang, C.-Q. Yang, W. Wang, T.-Z. Cao, M. Li, G.-Y Guo, J. Du, C.-L. Zheng, and Q. Zhu, "Predictors of Mortality for
Patients with COVID-19 Pneumonia Caused by SARS-CoV-2: A Prospective Cohort Study,” Eur. Respir. J., vol. 55, no. 5, 2020

[20] J. Yang, Y. Zheng, X. Gou, K. Pu, Z. Chen, Q. Guo, R. Ji, H. Wang, Y Wang, and Y. Zhou, "Prevalence of Comorbidities and Its Effects in Coronavirus Disease 2019 Patient: A Systematic Review and MetaAnalysis," Int J Infect Dis, vol. 94, pp. 91-95, 2020.

[21] R. Channappanavar, C. Fett, M. Mack, P.P. Ten Eyck, D.K. Meyerholz, and S. Perlman, "Sex-Based Differences in Susceptibility to Severe Acute Respiratory Syndrome Coronavirus Infection,” J. Immunol., vol. 198, no. 10, pp. 4046-4053, 2017.

[22] J.-M. Jin, P. Bai, W. He, F. Wu, X.-F. Liu, D.-M. Han, S. Liu, and J.-K. Yang, "Gender Differences in Patients with COVID-19: Focus on Severity and Mortality," Front. public Heal., vol. 8, p. 152, 2020.

[23] K. Liu, Y.-Y. Fang, Y. Deng, W. Liu, M.-F. Wang, J.-P. Ma, W. Xiao, Y.-N. Wang, M.-H. Zhong, and C.-H. Li, "Clinical Characteristics of Novel Coronavirus Cases in Tertiary Hospitals in Hubei Province," Chin. Med. J. (Engl)., vol. 133, no. 9, p. 1025, 2020.

[24] Q. Bi, Y. Wu, S. Mei, C. Ye, X. Zou, Z. Zhang, X. Liu, L. Wei, S.A. Truelove, and T. Zhang, "Epidemiology and Transmission of COVID-19 in 391 Cases and 1286 of Their Close Contacts in Shenzhen, China: A Retrospective Cohort Study," Lancet Infect. Dis., vol. 20, no. 8, pp. 911-919, 2020

[25] D.R. Petretto and R. Pili, "Ageing and COVID-19: What Is the Role for Elderly People?" Multidisciplinary Digital Publishing Institute, 2020.

[26] M. Bongiovanni, A. De Lauretis, G. Manes, A.M. Marra, B.D. Bodini, L. Pellegrini, S.A. Berra, D. Picascia, M. Schettino, and F. Bini, "Clinical Characteristics and Outcome of COVID-19 Pneumonia in Elderly Subjects," J. Infect., 2021.

[27] R. Muniyappa and S. Gubbi, "COVID-19 Pandemic, Coronaviruses, and Diabetes Mellitus," Am. J. Physiol. Metab., vol. 318, no. 5, pp. E736E741, 2020.

[28] R. Muniyappa and K.J. Wilkins, "Diabetes, Obesity, and Risk Prediction of Severe COVID-19," J. Clin. Endocrinol. Metab., vol. 105, no. 10, pp. e3812-e3814, 2020

[29] Z. Shahid, R. Kalayanamitra, B. McClafferty, D. Kepko, D. Ramgobin, R. Patel, C.S. Aggarwal, R. Vunnam, N. Sahu, and D. Bhatt, "COVID-19 and Older Adults: What We Know," J. Am. Geriatr. Soc., vol. 68 , no. 5, pp. 926-929, 2020.

[30] K. Prahasanti and M.R. Utama, "Pengaruh Komorbid Hipertensi Terhadap Severitas Pasien Yang Terinfeksi Covid 19," J. Implementa Husada, vol. 1, no. 2, pp. 136-151, 2020.

[31] L. Guo, D. Wei, X. Zhang, Y. Wu, Q. Li, M. Zhou, and J. Qu, "Clinica Features Predicting Mortality Risk in Patients with Viral Pneumonia: The MuLBSTA Score,” Front. Microbiol., vol. 10, p. 2752, 2019.

[32] A. Kamyshnyi, I. Krynytska, V. Matskevych, M. Marushchak, and O. Lushchak, "Arterial Hypertension as a Risk Comorbidity Associated with COVID-19 Pathology,” Int. J. Hypertens., vol. 2020, 2020.

[33] M. Witzenrath and W.M. Kuebler, "Pneumonia in the Face of COVID19." American Physiological Society Bethesda, MD, 2020. 